\title{
Democracy, Accountability, and Education
}

\section{Citation}

Levinson, Meira. 2011. Democracy, accountability, and education. Theory and Research in Education 9, no. 2: 125-144.

\section{Published Version}

doi:10.1177/1477878511409622

\section{Permanent link}

http://nrs.harvard.edu/urn-3:HUL.InstRepos:5372146

\section{Terms of Use}

This article was downloaded from Harvard University's DASH repository, and is made available under the terms and conditions applicable to Other Posted Material, as set forth at http:// nrs.harvard.edu/urn-3:HUL.InstRepos:dash.current.terms-of-use\#LAA

\section{Share Your Story}

The Harvard community has made this article openly available.

Please share how this access benefits you. Submit a story.

Accessibility 


\title{
Democracy, Accountability, and Education ${ }^{1}$
}

\author{
Meira Levinson \\ Harvard Graduate School of Education
}

Accepted on Feb. 2, 2011, for publication in Theory and Research in Education

\section{$\underline{\text { Abstract: }}$}

Educational standards, assessments, and accountability systems are of immense political moment around the world. But there is no developed theory exploring the role that these systems should play within a democratic polity in particular. Well-designed standards are public goods, supported by assessment and accountability mechanisms. They have the potential to serve democratic goods in particular, such as transparency, equality, and public discourse. Their very potential to advance systemic democratic goods, however, signals a level of reach and power that threatens the achievement of these same democratic values along other dimensions. This is especially evident in the contemporary United States. Adults' democratically legitimate control over education within a democracy may well undercut children's legitimate claims to receiving an education that equips them for democracy. Because education for democracy should trump education within democracy - and because evidence from the United States demonstrates the risks standards, assessments, and accountability systems can pose to democracies in general when they become too powerful — such systems should play only a limited role in democratic education reform that selects, trains, and provides on-going support to civically engaged and thoughtful educators. Under such circumstances, they may promote a virtuous circle that builds

\footnotetext{
${ }^{1}$ I am grateful to many interlocutors for their critiques of various earlier versions of this paper, and/or advice on particular issues. These include: Sigal Ben-Porath Eamonn Callan, Andrew Scott Conning, Randall Curren, Leslie Duhaylongsod, Walter Feinberg, Jane Gaskell, Daniel Koretz, Peter Levine, Cynthia Levinson, Sanford Levinson, Jal Mehta, Brendan Randall, Justin Reich, Rob Reich, Julie Reuben, Emily Robertson, Anna Rosefsky Saavedra, Robert Selman, Laurel Stolte, Kenneth Strike, Julia Van Alst, Jennifer Worden, and Melissa Williams. I also owe thanks for feedback that I received when I gave talks at the Philosophy of Education Society of New England, Centre for Ethics at the University of Toronto, Teachers College, Summer Institute of Civics Studies at Tufts University, and the Spencer Foundation's conference on Democracy, Scientific Expertise, and Education.
} 
capacity, motivation, and public support for strong and effective civic education practices, while still offering the adult public a strong democratic voice in public schools.

$\underline{\text { Key words: }}$

democracy, democratic education, standards, assessments, accountability

Educational standards, assessments, and accountability systems are of immense political moment in the United States and around the world. The United States alone has committed over five billion dollars in just the last couple of years to developing a new generation of state and national curriculum standards and assessments. Millions of dollars are raining down on districts to pay teachers for their students' performance gains on standardized tests and to implement new systems for holding students, teachers, and administrators accountable for students' academic performance on these tests. New proposed national math and reading standards were unveiled with great fanfare in the summer of 2010; forty-four states have already rushed to adopt them by January 2011. Superintendents, mayors, and even governors are tying their political and professional futures to the success or failure of these standards as well as the various assessment and accountability schemes that will accompany them. New York City Public Schools have made national headlines for plunging from outstanding to failing with the shift of a cut score. The Texas State Board of Education's revisions of their social studies standards to emphasize the Founders' Christian faith and eliminate Cesar Chavez from the curriculum have also attracted national and even international coverage. And of course, many students and teachers are working day in and day out to ensure that students pass tests at the required level, whatever that level happens to be. 
Amid all the sound and fury about standards, assessments, and accountability systems (which I will abbreviate as SAA from here on) and their implications for education, little has been said about the role that these systems should play within a democratic polity in particular. Do SAA systems promote or impede democratic values? In determining SAA mechanisms within and for democratic education, what is the appropriate role of and relationship between experts and ordinary citizens; children, parents, educators, and the interested public; empowered elites and historically marginalized others; majorities and minorities; local and more distant authorities? Are students likely to become more engaged and effective citizens with a welldesigned system of standards, assessments, and accountability measures or not? We don't know the answers to these questions, mostly because they haven't been asked. ${ }^{2}$ Instead, researchers have focused almost solely on the effects of SAAs on students' academic achievement. I am (perhaps perversely) relatively uninterested in this question — not because it doesn't matter, since it obviously does, but because it's not the only question that matters. The questions about SAAs' effects on democratic education, I assert, matter as much as those that query SAAs' effects specifically on students' academic achievement.

My aim in this article is thus to sketch out a democratic theory of educational standards, assessment, and accountability systems. This is a complex challenge, partly because of the number of moving parts (schools, policies, publics, kinds of assessments, etc.), partly because of the tensions between ideals and implementation, and partly because to do this right, I would need to take a stand on fundamental questions of democratic design, which I don't have room to do in this article. I hope, however, to delineate the main elements well enough to enable productive future work about the details.

\footnotetext{
${ }^{2}$ One important exception to this is (Strike).
} 
My overall thesis is that SAAs can simultaneously illuminate, serve, and undercut essential democratic purposes and mechanisms. Standards, I argue in section 1, are public goods. Insofar as assessment and accountability mechanisms are necessary to sustain and ensure compliance with standards, they serve the public good as well. Furthermore, I suggest in section 2, educational standards, assessments, and accountability mechanisms have the potential to serve the democratic good in particular in a number of ways. Ideals of equality, transparency, deliberation, and other democratic values are all potentially advanced by thoughtful SAA mechanisms. SAAs' very potential to advance systemic democratic goods, however, signals a level of reach and power that threatens the achievement of these same democratic values along other dimensions. Section 3 demonstrates the ways in which SAAs' capacities to clarify educational aims and outcomes and to empower ordinary citizens to assert authority over schools actually harms both educational and democratic practice in the contemporary United States. Furthermore, I argue in Section 4, SAAs' current uniform and fixed instantiation in the US make them spectacularly ill-suited to promoting high-quality civic education that will empower youth to become democratically engaged. Adults' democratically legitimate control over education within a democracy thus may well undercut children's legitimate claims to receiving an education that equips them for democracy. Section 5 suggests that democratic goods are best achieved through a limited SAA system. Given SAAs' at best ambiguous service to democratic education in the United States today — and given what these experiences demonstrate about the risks SAAs can pose to democracies in general when they become too powerful—SAAs should not serve as the centerpiece of education reform in a democratic society. Although at their best, they may provoke a virtuous circle of democratically-controlled education that serves young people's democratic ends, SAAs are most likely to promote democratic goods when they are 
embedded within an educational system that selects, trains, and provides on-going support to civically engaged and thoughtful educators.

$\underline{\text { Section 1: Standards, Assessment, and Accountability Mechanisms as Public Goods }}$

I argue that standards, assessments, and accountability measures have a role to play in public education within a democracy for two reasons. First, they are necessary to advance the public good. Second, they have the potential to enable specifically democratic goods. I explain why they are necessary in this section, and how they enable democratic goods in the next.

High-quality standards are a public good: in other words, everyone benefits from their existence, and the benefits derived by one person do not reduce the benefits derived by anyone else. ${ }^{3}$ The existence of standards in virtually all domains of life-from bridge building and telecommunications protocols to food safety, homebuilding, and automobile design — benefits everyone. It is impossible to imagine living a life, at least in the early 21 st century, in which there were no standards governing virtually all fields of endeavor in both the public and private spheres. We all benefit from driving in cars that meet safety standards on roads and bridges that do the same; this is true even if we don't ourselves drive, as our safety as pedestrians, say, relies in part on others' cars not careening into us due to shoddy automobile or road construction.

Similarly, we all benefit from eating food that is processed according to appropriate accepted standards and from accessing on-line media that accord with technical standards for distribution. Standards for public enterprises in particular — public schools, the judiciary, the military — are

\footnotetext{
${ }^{3}$ I should note that I am packing a lot into the term "high-quality." It's clear that the standards themselves need to surpass a certain level: meat-packing standards, for example, shouldn't be so low that contaminated meat could get through despite full compliance with the standards. But they also should be themselves designed to serve a public good. Hiring standards that are designed to reward nepotism over competence, or house lot size standards that intentionally price middle class and poor homeowners out of the neighborhood, are both examples of standards that are designed to serve private rather than public goods. So not all standards are a public good; but high-quality ones-i.e. those that set an appropriately high bar for the activity or output and that are themselves oriented toward a worthwhile aim — are public goods. I am grateful to Randall Curren for pressing this point with me.
} 
also public goods insofar as they help ensure the appropriate use and expenditure of scarce public resources. Governments should not tax people and spend resources on work that is shoddy, massively inefficient, or harmful. Since public resources will always be scarce, it is in the public interest to ensure that they are spent as wisely and effectively as possible.

Insofar as standards are necessary for all fields of endeavor, both public and private, it makes sense to expect that standards would be valuable in education as well. The expenditure of public resources on education should be made not wantonly but wisely, not haphazardly but with clear expectations and standards in mind. Furthermore, to the extent that well-developed educational standards establish high-quality educational practice, all citizens benefit. Educational standards, as much as any other standards, are a public good. To say this is not to say anything specific about the kinds, sources, range, or measures that the educational standards should represent. There is appropriately intense disagreement about all of these questions: Who should set standards? What kinds of standards should be set? What should the standards be? Who should assess the achievement of those standards? What should the consequences be for not meeting those standards? But the importance and even necessity of having public educational standards of some form should not itself be questioned.

If this is the case, I argue, then we must also accept the necessity of having public educational assessments and accountability measures. This is again for general reasons that don't have to do with education itself, but which do apply to public education as much as to any other public endeavor. Given human fallibility, standards are meaningless if there is no way to determine (via assessment) and ensure (via accountability) that they are being met. "Every meaningful standard offers a realistic prospect of evaluation; if there were no way to know whether anyone was actually meeting the standard, it would have no value or meaning. So, every 
real standard is subject to observation, evaluation, and measurement" (Ravitch, 1996: 9). In this respect, standards enable assessment, and assessment enables standards.

A corollary to this is that standards are limited to what can be assessed, and assessments are limited to what can be standardized. As a practical matter, therefore, assessment defines standards in practice. How a standard is assessed ends up guiding the understanding and actions of those attempting to meet the standard far more than any abstract articulation of the standard itself. More constructively, assessment permits the identification of "best practices" to achieve the standards; assessment enables standards to go from being mere expressions of distant dreams to becoming actionable goals. Related to this, assessment can also be used for standards-oriented diagnostic purposes - formative assessments, benchmarking, and so forth. All of these relationships between standards and assessments are independent of the role of accountability measures.

Assessments are also crucial, however, in enabling the development and imposition of accountability measures intended to motivate others to meet the standards. Assessments may be used as tools to hold various people or groups accountable for various reasons with respect to standards: in public education, these "accountability holdees" (Behn, 2003) may include students, teachers, administrators, school district, elected leaders, or citizens as a whole. ${ }^{4}$ Teachers may use student assessments to hold themselves or their students accountable; families and even students themselves may use assessments to hold schools accountable ${ }^{5}$; districts may assess to hold teachers or students accountable; citizens may use assessments to hold elected

\footnotetext{
${ }^{4}$ Gloria Ladson-Billings provides an especially interesting example of holding citizens as a whole accountable in her redescription of the individual "achievement gap" as a collective "education debt." See (Ladson-Billings, 2006) for more details.

${ }^{5}$ At The New School in Kennebunk, ME, for example, in which students and teachers democratically decide upon what courses will be offered each semester, students may require teachers to offer particular courses on the grounds that students need them to achieve state standards (Maine Learning Results) as demonstrated through their public portfolio presentations (Students and Faculty of The New School, 2010; see also The New School, 2010).
} 
leaders accountable, and so forth. In a celebrated series of state court cases during the 1990s, for example, citizen organizations such as the Campaign for Fiscal Equity used students' wretched test results to hold states responsible for providing an inadequate education to students particularly in poor and urban districts. Regardless of who is holding whom accountable for what, the general fact of accountability is necessary to give the standards and assessments "bite" - to make them meaningful guides to educational practice, as opposed to being seen as pesky distractions to the real work of teaching and learning.

Standards, assessments, and accountability measures are hence intrinsically interdependent and intertwined. If educational standards are deemed valuable, then educational assessments and accountability within education must be accepted as well. Note that this general statement is "platform independent" with regard to what kinds of standards, assessments, and accountability measures should be developed or imposed, by whom, or why. Standards may represent opportunity-to-learn, outcome, or process standards. Assessments might be formative or summative, standardized, portfolio-based, "authentic," norm-referenced or criterionreferenced, quantitative or qualitative. Accountability may be low or high stakes, individual or collective, financial or reputational or professional, negative or positive. They may be developed and applied at various levels: school, district, state, or nation as a whole. All of these distinctions are crucially important in practice, but they come after the prior truth of the necessary relationship among standards, assessment, and accountability.

\section{Section 2: The Democratic Virtues of SAA Mechanisms}

In the previous section, I gave a fairly generic and context-independent argument in favor of standards, assessments, and accountability measures. Standards serve the public good; standards are meaningless without assessment and accountability mechanisms; hence assessment 
and accountability mechanisms also are necessary to serve the public good. I now want to turn to the roles that standards, assessments, and accountability systems can play specifically within a democratic context. Even more specifically, I want to argue that SAA mechanisms can reflect and promote democratic values and goods; insofar as they do so, SAAs are not only permissible but actively desirable within a theory of democratic education.

SAAs may enact democratic values in at least six respects. First and probably most importantly, they often reflect democratic principles of equity. By establishing common expectations, whether of goals, opportunities, resources, or outcomes, common standards can reflect a commitment to the idea that all young people deserve the same quality education. It is worth noting that this is a fairly radical idea, even within a democracy. Although the United States has been a world leader in asserting the value of universal education and creating "common schools" intended to reflect democratic ideals (Reuben, 2005), what students have learned inside those schools has often intentionally varied wildly (see, e.g., Powell, Farrar and Cohen, 1985; Tyack, 2001; Oakes, 2005). Similarly, schools in different neighborhoods, districts, or states, as well as schools serving different populations of children as determined by race or ethnicity, class, immigration status, first language, and/or special needs status, for example, also had vastly differing resources and objectives and taught utterly different curricula - appropriately so, many people thought (Tyack and Cuban, 1995). So the assertion that all children should be given equal or at least adequate resources to master a common set of knowledge and skills is a fairly radical embrace of democratic notions of equality. The same can be said of the values underlying contemporary attempts to assess whether each child has in fact mastered the common curriculum and to hold educators, policy makers, or others accountable for children's success in doing so. The democratic significance of these values is important to 
emphasize even if the empirical outcomes of these policies are less equity-promoting than often intended.

Second, SAAs enact the value of efficiency. This is neither solely a democratic value nor by any means the most important democratic value (Stein, 2001), but it is still important to democracies. As I mentioned above, democracies always suffer scarce resources. It harms the democratic good if resources are used inefficiently, and especially if the public will is only partially realized because of ineffective and inefficient use of resources. Clear standards, assessments that appropriately measure achievement of those standards and enable educators and policy makers to increase achievement, and accountability measures that reward improvement may serve as essential tools for fostering efficiency.

Third, SAAs promote the democratic value of transparency. Instead of obscuring what, why, or how students are learning or confining knowledge of educational expectations to "experts," standards make educational goals and practices transparent to all citizens. Nowadays, it is easy for anyone with internet access to find out exactly what students at every grade level are expected to understand and be able to do in their own state, and to compare these expectations to those set by other US states and by other countries around the world. This is not only because of the power of the internet, but because of the transparency enabled by common standards. As a result, all citizens can get involved in supporting, challenging, or revising the standards that they find. Furthermore, common assessments make transparent to citizens whether their schools and their children are meeting these standards. Instead of being put off with bland reassurances that children are "doing fine," or being bought off with high grades or jazzy bulletin boards that are not true indicators of learning, citizens could use common, objective assessments to determine whether their schools are pursuing equitable goals, providing 
students equitable opportunities, and/or achieving equitable outcomes. This level of transparency is powerful, since with these standards and assessments in hand, parents and other citizens in a democracy can hold others accountable — including holding the state accountable in case of failure.

Fourth, the public construction of standards and assessments may promote democratic dialogue and deliberation. When SAAs are developed via public processes that invite considerable public input and dialogue, democratic relationships are fostered and democratic values are enacted. Such processes may even foster consensus-building about public priorities above and beyond the educational standards and assessments being developed. Individuals may come to the initial debate about what educational standards we should adopt with a diverse and conflicting array of perspectives. But as they discuss what students should learn, and as they relate these discussions to the bigger question of what kind of society we should be creating - to which the question about student learning inevitably connects - then citizens come to engage in a public dialogue and construct at least some common understanding about our public priorities. Under the best circumstances, public dialogue about standards, assessments, and accountability measures may also enable diverse citizens to come together around a common civic vision or democratic culture. ${ }^{6}$

\footnotetext{
${ }^{6}$ This isn't to say standards adoption always exemplifies the best of deliberative democracy. The Texas State Board of Education's recent revisions of Texas' history and social studies standards have been rightly reviled as an educational and democratic travesty. Similar outcry both preceded and followed Lynn Cheney and Rush Limbaugh's torching of proposed national history standards in the mid-1990s (Nash, Crabtree and Dunn, 2000). In the latter case, Cheney and Limbaugh's wholesale attack on the democratically-assembled standards resulted in the unprecedented act of the U.S. Senate voting 99-1 to censure the standards-before they were released and without anyone in the Senate's having read them. One reason that both the Texas State Board's and the U.S. Senate's actions are so frustrating, however, is that the standards in both cases were products of an incredibly inclusive and consensus-oriented process that actually did lead to the creation of thoughtful, critical, and balanced curriculum standards. These were eviscerated at the last minute by a group of elected representatives. Thanks to the Senate's actions, the United States has never adopted national history standards and likely will not do so for many more decades. It's no accident that both NCLB and the new Common Core State Standards have been silent on the subject of history and social studies. Thanks to the Texas State Board of Education's actions, Texas schoolchildren will now be taught that the American Founders believed in a Christian nation and that McCarthyism was justified.
} 
Fifth, democratically constructed SAAs can serve as a tool for enabling more robust democratic governance. One important justification of the value of democracy is its capacity to aggregate individuals' vast and diverse array of knowledge and perspectives; because of the range of knowledge and skills brought to bear, better choices are made by the group as a whole than could ever be made by a small cabal of leaders, no matter how intelligent and well-educated they were (Surowiecki, 2005). Correlatively, they enable (and instruct) teachers to base their practices on collective wisdom or expertise rather than on their individual whims or idiosyncratic knowledge. The tyranny of the individual teacher exercising her own judgment about what and how to teach is replaced by the authority of the democratic collective.

Sixth and last, by establishing some common goals or characteristics of schools, and common measures of anticipated outcomes, SAAs may foster diversity along other dimensions. This reflects the key liberal democratic values of freedom and diversity. If all schools are held accountable for achieving certain educational outcomes, then they can be left alone to determine their own means of achieving those outcomes. Because their students meet the standards, Big Picture schools can keep class time to a minimum, virtually eliminate specific academic requirements, and place students in compelling internships with photographers, auto mechanics, and biotechnology firms. Because their students meet the standards, KIPP schools can lengthen the school day and require Saturday school, mandate school-wide chants and rules about how to make eye contact, and drill reading and math skills. Montessori schools, expeditionary learning schools, proto-military academies, Deweyan learning communities, Essential Knowledge schools, farm schools, virtual schools that rely entirely on technology-mediated learning: all of these educational enterprises may flourish better in a system that uses common standards,

But in both cases, the initial state and national history standards developed through inclusive democratic deliberation and debate demonstrated greater breadth of vision than those constructed solely by a narrow slice of experts or by teachers working alone. 
assessments, and accountability mechanisms to safeguard that all students are learning than in one without SAAs but that mandates bureaucratic trivialities to control educators' work instead. In this way, too, SAAs may promote democratic values of diversity.

\section{Section 3-SAAs' Failures to Serve the Democratic Public Good}

For every democratic public good that standards, assessment, and accountability systems may promote, however, there is a correlative potential harm. SAAs may be based on collective prejudice and ignorance rather than wisdom; they may elevate public input to such a degree that they inappropriately discount expert knowledge; and they may promote consensus by preserving an exclusionary status quo rather than incorporating diverse voices. They may twist accountability into mistrust and develop standards via political maneuvering rather than public participation. Instead of promoting democratic dialogue, they may dissolve into vitriolic disputes about the "culture wars," promote standards and assessments that stymie youths' development of democratic capacities, and quash learning by overloading standards and expectations with trivia. Assessment and accountability mechanisms may lead even social liberationist schools to adopt "drill and kill" teaching methods, as in the case of Freire Charter School in Philadelphia, which features a photo on its website of individual desks in rows, trumpets its "many, very specific" required classes that leave no room for student input in the first two years, and even requires school uniforms (Freire Charter School, 2010). It's hard to imagine Paolo Freire embracing his namesake!

I suggest that many of these ills characterize SAA mechanisms as they have developed and been applied in the United States over the past few decades. Although this article is attempting to sketch out a theory of educational standards, assessments, and accountability in a democracy more generally, I believe that an examination of SAAs in the contemporary United 
States can prove quite useful. By seeing where SAAs have diverged from and even undercut their democratic potential, we gain insight into the characteristics and roles that SAAs need in order to be democratically justified.

Consider the intertwined and mutually interdependent nature of standards, assessments, and accountability mechanisms, for example. Assessments and accountability measures not only enable the establishment of meaningful standards, but also define and limit such standards. When we conceive of SAAs as the articulation and measurement of discrete bits of knowledge and skills-what we want students to "know and be able to do"-which is the case in the United States today, then we are disabled from setting educational goals about the kinds of people we would like our students to become and the kinds of holistic challenges we would like them to be able to meet. Relatedly, assessments that are sufficiently objective to enable fair and transparent accountability mechanisms often fail to be sufficiently flexible and context-dependent to measure the kind of standards mastery citizens care about or to promote best practices (DarlingHammond, 2004). Furthermore, accountability measures may promote educators', students', and others' adherence to and achievement of the standards, but they may also pervert incentives and distract educators and students from the real work and value of learning.

These ills arise in large part because SAAs are necessarily blunt rather than fine-grained. They necessarily cannot specify, assess, or hold students or educators accountable for mastering every piece of knowledge or skill that is considered valuable (Archbald and Newmann, 1988; Wasserman, 2001; Koretz, 2008). When standards do try to get so specific, they quickly overwhelm teachers and students alike. Furthermore, accountability systems that impose consequences for multiple dimensions of student performance may also sink under their own weight. This has been one significant problem with the US federal education law No Child Left 
Behind (NCLB). It measures schools' "Adequate Yearly Progress" (AYP) with respect to up to twenty-two different subgroups . Failure to make AYP for any one subgroup has resulted in the school's being deemed a failure overall—a result that has afflicted over one-third of all US schools (Dillon, 2009: 2), and nearly half of schools in some states (Darling-Hammond, 2004; Wiley, Mathis and Garcia, 2005: ii). It is a bit of a Catch-22; the greater the number and rigor of the criteria that students and schools are held accountable for meeting, the greater the chance that students and schools will fail to meet all of the criteria, and the less likely they will be either to build upon their successes or to concentrate on a few high-value domains of improvement. Standards, assessments, and accountability measures are stuck in the Goldilocks dilemma: there can't be so many that they overwhelm students or the system, and there can't be so few that they shrink the curriculum and provide little support for or information about student learning. They need to be "just right." But even when they are just right (assuming we know what that means), they still necessarily provide only blunt expectations for and standards of success, which then in turn makes them crude tools for educational evaluation, improvement, or reform.

As I argue in Section 5, this means that SAAs should not and cannot be used as the primary drivers of educational improvement and reform. We can resolve the Goldilocks dilemma only by reducing what SAAs are responsible for being "just right" about. In the United States in 2011, however, SAAs are being called upon to do more rather than less. US public schools are being asked to adhere more closely to more dense and demanding standards that frankly occupy more hours in the day than students actually attend school. It is possible that the new Common Core State Standards will ameliorate this problem, but it's certainly too soon to know. The stakes are also being raised ever higher, and educators are being asked to engage in ever more specific "data-driven" instruction. However, complex standards measured by high-quality, valid, 
reliable assessments are extremely time-consuming and expensive to develop, administer, and evaluate (Koretz, 2008; Toch, 2006). Relatively quick and/or cheap SAA systems are hence frequently adopted instead. Sadly, these are inevitably simplistic and pointless, or even outright harmful, as they privilege superficial knowledge and easily-measured skills over deep knowledge, complex skills, attitudes, habits, or behaviors (see Sacks, 2000; Herman, 2003; Darling-Hammond, 2004; Ulluci and Spencer, 2009; Winerip, 2006).

Since standardized assessments end up measuring and accountability systems end up rewarding subsets of what is educationally valued - whether to reduce the cost of developing and scoring the assessments, to reduce the amount of time students spend taking tests, to enable the assessment of the same knowledge and skills over time so as to permit longitudinal comparisons, or other reasons - they risk further perverting educational practice in a variety of ways. Most fundamentally, they skew teachers' instructional efforts toward the narrower content range and even the format and other essentially arbitrary features of the test itself, rather than toward the full range of educational standards or (most importantly) toward student learning (Koretz, 2008). Robert Behn summarizes the general problem clearly: "“What gets measured gets done' is, perhaps, the most famous aphorism of performance measurement. If you measure it, people will do it. Unfortunately, what people measure often is not precisely what they want done. And people - responding to the explicit or implicit incentives of the measurement - will do what people are measuring, not what these people actually want done.” (Behn, 2003: 569)

SAA mechanisms in the United States thus typically end up promoting compliance rather than educational improvement. This should not be surprising, Richard Elmore argues, since SAAs are rarely designed with a theory of improvement in mind:

While state and federal accountability systems may be improvement-oriented in intent, they are often compliance-oriented in practice. In order for an accountability system to 
be based on improvement, it has to embody an underlying theory of how schools improve their performance. Simply constructing an incentive structure of standards and testing around the expectation of steady improvements in performance is not a theory of improvement. A theory of improvement actually has to account for how people and schools learn what they need to know in order to meet the expectations of the accountability system. By this standard, no existing state or federal accountability system is improvement-oriented. (Elmore, 2005: 294)

This mismatch between goals and outcomes also partly accounts for the frequent misuse of SAA systems, including making decisions that assessments were not designed to address, drawing conclusions the data cannot support, or imposing high-stakes rewards and punishments on the basis of a single, necessarily imperfect test and/or with utter disregard for the measurement limitations inherent in the test (Linn, 2000; Fuhrman and Elmore, 2004; Curren, 2004; Koretz, 2008).

Furthermore, many of the democratic goods that SAAs have the potential to advance are equally likely to be retarded thanks to SAAs' power and reach. For example, although SAAs foster some forms of educational diversity, they stymie other equally desirable dimensions of democratic diversity. At the end of the last section, I gave examples of how SAAs enable pedagogical and structural diversity given common learning goals. But of course, insofar as the learning goals themselves are fixed—insofar as they are codified into standards that all students are expected to achieve - then they necessarily restrict diversity along that very dimension. To the extent that they defined a whole rather than just part of schooling, therefore, SAA mechanisms threaten to neglect the authentic range of educational needs and desires among the diverse array of communities and young people within contemporary democratic states. Individual students with a diverse array of passions—-for creative writing, chemistry, hip hop, environmental justice, dairy farming, cars, on-line gaming, mathematics, Navaho history - may be prevented from developing their knowledge and skills because of the lock-step requirements imposed by comprehensive, time-intensive SAA mechanisms. In addition, students and 
communities that have strengths in domains not recognized or covered by state standards and assessments—-strengths such as bilingualism, biculturalism, moral reciprocity, or deep understanding of the natural environment, for example — fail to be "credited" with these capacities or encouraged to build on and develop these strengths further; instead, only their "deficits" in relation to the established standards are noted and "remediated." These failures of SAA systems to foster legitimate and even desirable forms of diversity within a pluralistic democracy harm individuals and the democratic polity alike.

To the extent that standards define and limit what is taught as "common knowledge," the diverse range of knowledge and skills that strengthen democratic deliberation and action may especially be eroded. Christine Sleeter argues:

Allowing for development of diversity and expertise can serve as an intellectual resource for constructive participation in a multicultural democracy and a diverse world. It is to our benefit that we do not all learn the same thing, beyond the basic skills. Helping next generations acquire intellectual resources of diverse communities, including those that have been historically silenced, can enable creative dialogue and work, out of which we might better address problems that seem intractable. (Sleeter, 2005: 7)

It is important to recognize here that the critique is not that standards reflect a particular privileged viewpoint (say that of white, Christian males) or that they exclude historically marginalized perspectives. In this case, common standards would be perfectly acceptable so long as they were more inclusive of diverse voices. Rather, the critique is that democracy itself is weakened when all students learn only one set of ideas and skills, no matter how inclusive and worthwhile those ideas and skills are. Diversity is the strength of democracy, not a weakness. To the extent that standards-driven instruction, reinforced by standardized assessments and highstakes accountability measures, reduce the array of knowledge and skills available to the polity, SAA measures may have profoundly antidemocratic outcomes. 
Related to this, to the extent that standards, assessment, and accountability systems move upstream from individual educators, parents, and communities to higher-level aggregationswhether school districts, states/provinces, or even the nation - they run the risk of reducing local democratic control. As Archon Fung demonstrates in his analysis of Chicago police and schools, it is possible to avoid this outcome through "accountable autonomy" measures at the local level that actually increase local, democratic "empowered participation" (Fung, 2004). But this relationship is inherently quite fragile, and it depends on many of the goals (standards), measures (assessments), and accountability outcomes to be set at the local level in a collaborative fashion between public officials and community members.

Furthermore, many people appropriately fear any additional aggregation of power and control by the state, especially over the education of young citizens. As standards, assessments, and accountability measures become ever more tightly linked — a phenomenon that is lauded within education policy circles because such integration represents greater conceptual and organizational coherence - they also inevitably get closer to defining and privileging "official knowledge." Whether the concern is that such official knowledge will be partisan, protective of those in power, disempowering to those who hold different viewpoints perspectives, necessarily partial, blinkered, or self-serving in some other way, the general concern remains that the state should not be in the position of defining and hence limiting the scope of knowledge and skills to be acquired by the next generation of citizens. This reverses the appropriate democratic relationship between the state and citizen, it is argued, where the citizen exercises voice and power to influence the state and not the other way around. Although I am fairly dubious about this argument on individual rights-oriented grounds - as I have discussed in detail elsewhere (Levinson, 1999), from the child's perspective schooling controlled by a democratic state is 
probably less limiting than schooling controlled by her parents-I do think this argument has considerable merit from an empirical perspective. Knowledge will inevitably be less limited, less subject to state censorship or control, more representative of the extremes of opinion and not just the inherently conservative "safe middle," and more freely available if there is educational diversity rather than a set of state-imposed hegemonic standards, assessments, and accountability measures.

A final potential threat posed by SAAs to education within a democracy results from their use as both implicit and explicit sorting mechanisms. They sort knowledge and skills, students, teachers, schools, administrators - everything and everyone ends up being assigned a relative value: worthy of inclusion or not, high achieving vs. low achieving, effective versus failing, eligible for a specific set of goods (promotion to the next grade level, merit pay, graduation, etc.) or not (Sacks, 2000). This sorting may (or may not) be justified on policy-oriented grounds, but we should nonetheless recognize and acknowledge that it stands in significant tension with democratic values. Democracy entails civic equality among citizens-equality of political voice, and equality before the law. To the extent that standards, assessment, and accountability systems are now sorting young people — young citizens — as early as seven or eight years old and annually after that, we should at least question the democratic implications of SAAs' position in the contemporary educational landscape.

\section{Section 4-SAA's Threat to Educating for Democracy}

Speaking of young people, I focus in this section on youth as an additional "democratic public" with legitimate claims of their own. In essence, I want to shift our attention from SAAs' roles within one conception of democratic education-namely, of education within a democracy — to their role within a second conception — namely, of education for democracy. 
Democratic education understood as education within a democracy focuses on what makes an educational system democratically justified, in particular on the extent to which public schools must be subject to adult citizens' democratic deliberation and control in order to be legitimate. ${ }^{7}$ This is the question that we have thus far been examining - in particular, we've been focused on how SAAs enable or stymie adults' democratic control over education both in theory and in contemporary practice in the United States. The second way to understand democratic education, however, focuses on young people's development of civic capacities rather than adults' exercise of their capacities. Education for a democracy is that which enables the next generation of citizens to participate in, promote, and preserve representative democracy in the future. Young people are at the center of this conception of democratic education, and their civic empowerment is its primary goal. I believe we need to take this second conception of democratic education as seriously as we've taken the first in developing a democratic theory of educational standards, assessment, and accountability systems. ${ }^{8}$

In this section, I argue that SAAs may be ill-suited to education for democracy's longerterm goals of transforming the United States into an egalitarian society in which today's often disempowered youth become tomorrow's critically engaged, efficacious, and empowered adult citizens. This is so for two reasons. First, standardized goals, content, and assessments are uniform and static whereas empowering civic education is particular, context-specific and

\footnotetext{
${ }^{7}$ Private schools are also relevant in this discussion, but I will ignore them for the sake of simplicity.

${ }^{8}$ In her seminal book Democratic Education, Amy Gutmann sets goals based on both conceptions of democratic education without necessarily recognizing their potential contradiction. She articulates the goal of what I call education for democracy as follows: "all citizens must be educated so as to have a chance to share in selfconsciously shaping the structure of their society" (Gutmann, 1987: 46). In this formulation of democratic education, she is arguing that young people should learn the knowledge and skills necessary to be civically empowered. Earlier, however, she claims, "A democratic theory of education focuses on what might be called 'conscious social reproduction' - the ways in which citizens are or should be empowered to influence the education that in turn shapes the political values, attitudes, and modes of behavior of future citizens" (Gutmann, 1987: 14). In this formulation of democratic education, she is arguing that adults should be able to exercise democratic power over education. This is education within a democracy, not education for a democracy. Gutmann attempts to reconcile these through principles of nonrepression and nondiscrimination, but the arguments of this section suggest something more is required.
} 
dynamic. Second, standards, assessments, and accountability mechanisms that are developed by people or groups outside the school — district or state administrators, national expert groups, or even local citizens - and then imposed upon teachers and students in the school inherently undermine good civic education by removing the locus of control from teachers who need to model empowered democratic civic action and students who need to practice it.

To begin with, if we want young people to become inclined and empowered to participate meaningfully and effectively in democratic civic and political life, then they need to master at least some location- and context-specific knowledge and skills. Even within a single state or region, the structures and power dynamics of local civic and political institutions vary widely. Towns may be governed by a strong mayor, a weak mayor in collaboration with the city council, a city manager, or some other structure. The schools, public housing authority, and parks departments may be subject to mayoral control, controlled by the county or state, or function as independent agencies with directly elected governing boards (among other possibilities). A city may have a strong and civically involved business community and a thriving civil society or none at all. Students may live on farms and travel up to twenty-five miles to attend a regional comprehensive high school; alternatively, they may live and be educated in a small, rural town, a suburban bedroom community, a dying industrial city, or a booming metropolis. These differences matter and need to be accounted for if students are to learn how effectively to exercise civic and political power. Whether they want to advocate for more youth summer employment opportunities or get a skateboarding area added to the design for the new park, they need to know whom to contact and work with and how, and this will differ from place to place.

It is not only civic and political structures whose particularities matter with respect to civic education. Many of the other good civic education practices listed above also demand 
significant contextual flexibility and variation. How a school constructs and maintains a "procivic" culture will necessarily vary widely depending on the educational and civic context. A small school with a relatively homogeneous and stable student population will inevitably and appropriately build a different kind of pro-civic school culture than a large school with a highly transitory and diverse population. Schools in neighborhoods plagued by gang violence and ethnic tensions may work to create a civic school culture that emphasizes safety, mutual respect, and a willingness to identify shared goals across lines of apparent difference; a school located in a highly stable and even insular neighborhood, by contrast, may strive to create a civic culture that provokes respectful disagreement and dislodges students from their conformist complacency.

Furthermore, the kinds of civic skills and attitudes that young people need to develop in order to be empowered participants in democratic civic and political life vary depending on individual and community context. Minority students and communities may need to be able to “codeswitch" (Cross Jr., Strauss and Fhagen-Smith, 1999; Delpit and Dowdy, 2002; Carter, 2005) — to express themselves in language used by and familiar to the majority community rather than in the language of their home communities. Such codeswitching may represent a shift from Black Vernacular English to Standard American English, from religious to secular language (or vice versa), or from cultural references that are familiar only to the minority group to those that resonate with the majority group as well. The ability to shift like this is key to acquiring and exercising power effectively in a democracy based on majority rule (Levinson, 2003)—but it is not an easily standardized goal or practice. On the flip side, members of majority and/or privileged groups may need to be taught about the existence and persistence of injustice in society; they may also need to learn that these injustices are partly systemic rather than simply 
examples of individual wrongs done to others. This is an equally crucial component of good democratic education - but is probably as unnecessary in communities with substantial on-going experiences of injustice as teaching codeswitching is in communities that already speak the "language of power" (Delpit, 1995).

In addition to being particular and contextual, good civic education as I describe it above is also dynamic. Relevant content is continually shifting in response to current events and local issues. In the four semesters that I taught eighth grade civics, for example, I taught four very different curricula. In Fall 2004, we focused on the presidential elections. In Fall 2005, we examined the causes and consequences of Hurricane Katrina's devastating attack on the Gulf Coast. We were able to use something my students actually cared about to explore federalism, the rule of law, separation of powers, individual vs. collective responsibility, geography, demographic analysis, media literacy and critical analysis of public rhetoric ("refugees from" versus “survivors of" the hurricane). As a civic matter, too, we were able to orient students' energies and outrage toward constructive and effective action. But we didn't cover the court system, or parliamentary systems, or a number of other items included in the district standards. Civic education is also dynamic insofar as it incorporates guided experiential education — doing civics, not just learning about civics. Young people should have the opportunity to "practice" civic engagement throughout their schooling in order to become civically engaged and empowered adults (Levinson, 2010). What students experience, how they experience it, what help they will need in making sense of their experiences: all of these are unpredictable and extremely dynamic features of teaching and learning. They are also obviously particular with respect to each student and his/her specific experiential context and task. 
In all of these examples, good civic education is demonstrably contextual, particular, and dynamic - the opposite of standardized, common, and static, i.e. the characteristics of standards and assessment systems. To the extent that standards specify exactly what content and/or skills students will learn, or what issues may be covered, and to the extent that psychometrically valid standardized assessments are then used to assess students' mastery of the standards, these will both in principle and in practice work against the dynamism and contextual grounding of good civic education. ${ }^{9}$

The other way in which standards and assessment systems that apply across schools and districts work against good civic education is by removing the locus of control from those who want and need to model empowered civic action — teachers — and those who want and need to practice empowered civic action—students. When teachers are working in a system that denies them the opportunity to exercise professional judgment or democratic voice or participation, they cannot model the "arts of democratic life" (Meier, 2003: 16). Even more to the point, they can't model empowerment if they feel totally disempowered. Similarly, students can't practice democracy, or experience empowerment, if they have no voice and no power in determining

\footnotetext{
${ }^{9}$ Two examples may help make this threat more concrete. I teach a pedagogical methods course for graduate students at the Harvard Graduate School of Education who are studying to become urban public school teachers. These are smart, passionate, driven educators who reflect constantly about improving their practice. We met for class one evening (Sep. 29, 2008) after the U.S. House of Representatives voted to reject the proposed bank bailout in the early days of the 2008 financial catastrophe. I asked my students, most of whom had been at their school site that day, how many of them or their mentor teachers had discussed the House vote, or even any aspect of the global financial meltdown, with their students. Only one of the sixteen students raised her hand. When I probed further, they revealed that it just hadn't occurred to most of them, nor apparently to their mentor teachers, that they might discuss it with their students. It wasn't that they had thought about addressing the unfolding economic catastrophe but felt too pressured by the pacing guide or the tests to take time out to do so. Rather, they were so standardsdriven that it didn't even occur to them to look beyond them for what to teach. This replicated a phenomenon I observed earlier that spring, when another student wrote up a two-week unit on voting for the eighth grade Civics in Action course she was student teaching. Even though she was teaching voting in February 2008, during the most exciting presidential primary race in a generation and overlapping with Massachusetts' participation in Super Tuesday primaries, it didn't initially occur to her to include anything about the current election. After all, she was following the standards. Diana Hess provides perhaps the most sobering account of all, of a teacher who claimed in Fall 2001 that "she only had two class periods to 'do' the War of 1812 and so she simply could not spare the time to focus on 9/11" (Hess, 2009: 42).
} 
what they learn, why, how, or when. In this respect, the imposition of standards, assessment, and accountability measures upon teachers and students, no matter how wonderful they are (i.e. even if they could overcome the other concerns I have raised), intrinsically undermines good civic education.

This is ultimately where the conflict between SAAs' use within schools as expressions of democratic agency among adults and SAAs as tools for promoting young people's development of democratic agency - i.e. between education within democracy and education for democracycomes to a head. There are good reasons to have adults democratically involved in setting public educational standards, assessments, and accountability measures. In so doing, adults get to participate in enacting and promoting democratic values through means that also reflect democratic principles. As Terry Moe puts it, rather more contentiously:

The public schools are agencies of democratic government, created and controlled by democratic authorities. They are not free to do what they want. Everything about them, from goals to structure to operations, is a legitimate matter for decision by their democratic superiors and subject to influence by the political processes that determine who those superiors are and how they exercise their public authority. (Moe, 2000: 127)

This is a powerful articulation of schools as sites of democratic governance. But at the same time, Moe's assertion reveals how treating the school as a site or tool of democratic governance can be extremely disempowering and antidemocratic in its effect on teaching students to be democratic citizens and agents. Students' voices are ignored in the formulation above. Theyand teachers - are not recognized as democratic equals, but instead are treated as subordinates to their "democratic superiors" and to "democratic authorities." Teachers are also unable to practice or model democratic agency in this formulation. They become demoralized and apathetic - they wait for decisions to come down the pike to them to implement - and hence cannot model or develop beliefs in democratic agency and participation to share with their students. In this respect, SAAs' potential to enable collective democratic control over schools 
risks disabling young people's individual development of democratic capacities and inclinations within schools. I summarize the tensions in columns A and B of Table 1.

[Insert Table 1 about here.]

\section{Section 5: Squaring a Virtuous Circle-Limiting SAAs for the Sake of Democracy}

An ideal system of standards, assessments, and accountability mechanisms would somehow enable and achieve the best of each of these worlds without succumbing to the dangers I've introduced above. They would give us a means of avoiding the kinds of perverse incentives and outcomes that infect education in the United States today. They would also explicitly reflect, enact, and promote the democratic values and principles that lie at the heart of legitimate democratic civic education. Because this utopian ideal is not possible, however, serious reform or implementation of educational standards, assessment, and accountability mechanisms in a democracy must confront these tensions directly.

To begin with, I suggest that we need to reduce educational standards, assessments, and accountability mechanisms' reach over schools. In the United States, they govern virtually every aspect of educational practice. This is not the case in other developed countries. In England, for example, the National Curriculum, along with its associated assessments, is intended to take up approximately two-thirds of students' and teachers' time. This permits (in theory, at least) the collective to exercise some control over schools while also leaving teachers and students free to exercise their own judgment and local control over teaching and learning. If 50-60\% of students' time was taken up meeting publicly-created standards in the United States, that would still leave a lot of time for the kinds of good civic education practices I value. It would also leave room for 
the kinds of democratic diversity of values, community characteristics, and practices that I argued in Section 3 are threatened by overly-comprehensive SAA systems. Furthermore, if some of the SAAs were created distally and some more locally, that might provide the right balance of equity (comparing students in urban and suburban schools along similar dimensions) and local/community responsiveness (doing what's right by a particular set of students).

Second, when SAAs truly do force hard choices, we must prioritize education for democracy over education within democracy. Although I don't have space to argue for this fully here, I think that schools should serve students' democratic interests in becoming empowered citizens over adults' democratic interests in expressing their values.

At the same time, we must recognize that SAAs are neither the sole nor even most effective means of fostering democratic goods and improving civic education. We cannot standardize and assess ourselves into civic greatness, if for no other reason than that the perverse interactions among standards, assessments, and accountability mechanisms are just too great fully to overcome. Rather, SAAs are one small tool among many approaches necessary for fostering good civic education and democratic practice. These other approaches include: effective teacher recruitment and selection that takes civic propensities and skills into account; extensive professional development at all stages of educators' and administrators' careers; increased resources (time, money, scheduling, instructional minutes/courses); effective and empowering professional networks of educators who are committed to enacting and improving civic education; and public outreach and even "messaging" designed to change the public conversation about the purposes of schooling and the place and models of civic education that we should pursue as a result. 
Admittedly, none of these approaches fully addresses the issue that schools are sites of civic engagement, and hence that democratic control is likely to trump these "expert" recommendations. This is essentially a chicken-and-egg problem. Until schools implement an effective and empowering civic education, it is unlikely that most adults will know or care to take the issue on. But unless they do, schools will likely have little motivation or opportunity to improve the civic education on offer. My hope, nonetheless, is that the recommendations above will help create a virtuous circle in which public schools within democracies are enabled and empowered by the citizens who exercise "authority" (Moe, 2000: 127) over them to offer an education for democracy. Column $\mathrm{C}$ of Table 1 summarizes this more egalitarian and civicminded democratic vision. If this virtuous circle can get started, then it may build capacity, motivation, and public support for strong and effective civic education practices, while still offering the adult public a strong democratic voice in public schools. 
Table 1: Standards, Assessment, and Accountability Systems Within and For Democratic Education

\begin{tabular}{|c|c|c|c|}
\hline & $\begin{array}{l}\text { A. Schools as Sites of Adults' } \\
\text { Democratic Engagement: } \\
\text { "Education within democracy" }\end{array}$ & $\begin{array}{l}\text { B. Schools as Tools for Students' } \\
\text { Democratic Empowerment: } \\
\text { "Education for democracy" }\end{array}$ & $\begin{array}{l}\text { C. Schools as Sites of Adults' } \\
\text { Enlightened Democratic } \\
\text { Engagement: "Education within a } \\
\text { truly civic democracy" }\end{array}$ \\
\hline \multirow[t]{5}{*}{$\begin{array}{l}\text { Goals, Sources, } \\
\text { and Content of } \\
\text { Standards }\end{array}$} & $\begin{array}{l}\text { Variety of aims (civic learning one of } \\
\text { many) }\end{array}$ & Civic learning is primary aim & $\begin{array}{l}\text { Variety of aims_-but civic learning } \\
\text { will be recognized as a central goal of } \\
\text { public education }\end{array}$ \\
\hline & $\begin{array}{l}\text { Potentially conservative: reflect } \\
\text { current power differentials, current } \\
\text { consensus, status quo }\end{array}$ & $\begin{array}{l}\text { Potentially radical, transformative: } \\
\text { strive for a society in which citizens } \\
\text { are equally engaged and empowered }\end{array}$ & $\begin{array}{l}\text { Reflect current consensus in favor of } \\
\text { robust democratic engagement }\end{array}$ \\
\hline & Responsive to current anxieties & Oriented toward future needs/issues & $\begin{array}{l}\text { Responsive to current aspirations for a } \\
\text { robust civic sphere }\end{array}$ \\
\hline & $\begin{array}{l}\text { Standards are means of expressing } \\
\text { public will }\end{array}$ & $\begin{array}{l}\text { Standards focused on creating } \\
\text { democratically-minded and } \\
\text { empowered citizens }\end{array}$ & $\begin{array}{l}\text { Standards are means of collaboratively } \\
\text { constructing a deliberative public } \\
\text { conception of democratic goods }\end{array}$ \\
\hline & Expertise lies in collective wisdom & $\begin{array}{l}\text { Expertise may reside in experts in } \\
\text { civic education (researchers, } \\
\text { educators, etc.) }\end{array}$ & $\begin{array}{l}\text { Expertise lies in informed collective } \\
\text { wisdom }\end{array}$ \\
\hline Assessments & $\begin{array}{l}\text { Tools for enabling public to hold } \\
\text { teachers and schools accountable for } \\
\text { fulfilling public will }\end{array}$ & $\begin{array}{l}\text { Means to determine whether students } \\
\text { are mastering the knowledge and } \\
\text { skills needed for civic empowerment }\end{array}$ & $\begin{array}{l}\text { Tools for enabling an engaged, } \\
\text { democratic public to hold teachers and } \\
\text { schools accountable for fostering an } \\
\text { empowering civic education }\end{array}$ \\
\hline
\end{tabular}




\begin{tabular}{|c|c|c|c|}
\hline & Visible - current practice & Invisible - future outcomes & $\begin{array}{l}\text { Visible demonstrations of civically } \\
\text { engaged and empowering teaching } \\
\text { practices }\end{array}$ \\
\hline \multirow[t]{2}{*}{ Accountability } & Oversight-oriented & Trust-oriented & Oversight-oriented \\
\hline & $\begin{array}{l}\text { Accountable to current citizens; adults } \\
\text { primary accountability holders }\end{array}$ & $\begin{array}{l}\text { Accountable to students/future active } \\
\text { citizens; students primary } \\
\text { accountability holders }\end{array}$ & $\begin{array}{l}\text { Accountable to democratic society as a } \\
\text { whole }\end{array}$ \\
\hline
\end{tabular}




\section{Bibliography}

Archbald, D. and F. Newmann (1988) Beyond Standardized Testing: Assessing Authentic Achievement in the Secondary School. Reston, National Association of Secondary School Principals.

Behn, R. D. (2003) 'Why Measure Performance? Different Purposes Require Different Measures'. Public Administration Review 63(5): 556-76.

Carter, P. (2005) Keepin' It Real: School Success Beyond Black and White. New York, Oxford University Press.

Cross Jr., W. E., L. Strauss and P. Fhagen-Smith (1999) 'African-American Identity Development Across the Life Span: Educational Implications', in R. H. Sheets and E. R. Hollins (eds.) Racial and Ethnic Identity in School Practices: Aspects of Human Development. Mahwah, NJ, Lawrence Erlbaum Associates: 29-47.

Curren, R. R. (2004) 'Educational Measurement and Knowledge of Other Minds'. Theory and Research in Education 2(3): 235-53.

Darling-Hammond, L. (2004) 'From 'Separate But Equal' to 'No Child Left Behind': The Collision of New Standards and Old Inequalities', in D. Meier and G. Wood (eds.) Many Children Left Behind: How the No Child Left Behind Act is Damaging Our Children and Our Schools. Boston, Beacon Press: 3-32.

Delpit, L. (1995) Other People's Children. New York, The New Press.

Delpit, L. and J. K. Dowdy, eds. (2002) The Skin That We Speak: Thoughts on Language and Culture in the Classroom. New York, The New Press.

Dillon, E. (2009) 'Moving Targets: What It Now Means to Make 'Adequate Yearly Progress' Under NCLB.' Explainer.

Elmore, R. F. (2005) 'Agency, Reciprocity, and Accountability in Democratic Education', in S. Fuhrman and M. Lazerson (eds.) The Public Schools. New York, Oxford University Press: 277-301.

Freire Charter School. (2010) 'Freire Charter School Home'. Available at http://www.freirecharterschool.org/index.htm (accessed March 3, 2010).

Fuhrman, S. and R. Elmore, eds. (2004) Redesigning Accountability Systems for Education. New York, Teachers College Press.

Fung, A. (2004) Empowered Participation: Reinventing Urban Democracy. Princeton, NJ, Princeton University Press.

Gutmann, A. (1987) Democratic Education. Princeton, Princeton University Press.

Herman, J. (2003) 'The Effects of Testing on Instruction', in S. Furhman and R. Elmore (eds.) Redesigning Accountability Systems for Education. New York, Teachers College Press: 141-66.

Hess, D. E. (2009) Controversy in the Classroom : The Democratic Power of Discussion. New York, Routledge.

Koretz, D. (2008) Measuring Up: What Educational Testing Really Tells Us. Cambridge, Harvard University Press.

Ladson-Billings, G. (2006) 'From the Achievement Gap to the Education Debt: Understanding Achievement in U.S. Schools'. Educational Researcher 35(3): 3-12.

Levinson, M. (1999) The Demands of Liberal Education. Oxford, Oxford University Press.

Levinson, M. (2003) 'Challenging Deliberation'. Theory and Research in Education 1(1): 23-49. 
Levinson, M. (2010) 'The Civic Empowerment Gap: Defining the Problem and Locating Solutions', in L. R. Sherrod, J. Torney-Purta and C. A. Flanagan (eds.) Handbook of Research on Civic Engagement in Youth. Hoboken, NJ, John Wiley \& Sons: 331-61.

Linn, R. R. (2000) 'Assessments and Accountability'. Educational Researcher 29(2): 4-16.

Meier, D. (2003) 'So What Does It Take to Build a School for Democracy?'. Phi Delta Kappan 85(1): 15-21.

Moe, T. M. (2000) 'The Two Democratic Purposes of Public Education', in L. M. McDonnell, P. M. Timpane and R. Benjamin (eds.) Rediscovering the Democratic Purposes of Education. Lawrence, Kansas, University Press of Kansas: 127-47.

Nash, G. B., C. Crabtree and R. E. Dunn (2000) History on Trial: Culture Wars and the Teaching of the Past. New York, Vintage.

Oakes, J. (2005) Keeping Track: How Schools Structure Inequality, Second Edition. New Haven, CT, Yale University Press.

Powell, A. G., E. Farrar and D. K. Cohen (1985) The Shopping Mall High School: Winners and Losers in the Educational Marketplace. New York, Houghton Mifflin.

Ravitch, D. (1996) '50 States, 50 Standards'. Brookings Review 14(3): 6-9.

Reuben, J. (2005) 'Patriotic Purposes: Public Schools and the Education of Citizens', in S. Fuhrman and M. Lazerson (eds.) The Public Schools. Oxford, Oxford University Press: $1-24$.

Sacks, P. (2000) Standardized Minds: The High Price of America's Testing Culture and What We Can Do to Change It. Cambridge, Da Capo.

Sleeter, C. E. (2005) Un-Standardizing Curriculum: Multicultural Teaching in the StandardsBased Classroom. New York, Teachers College Press.

Stein, J. G. (2001) The Cult of Efficiency. Toronto, House of Anansi Press.

Strike, K. A. 'The Ethics of Accountability'.

Students and Faculty of The New School, K., ME (2010). Panel Discussion: Alternatives in Schooling. Cambridge, MA, Harvard Graduate School of Education.

Surowiecki, J. (2005) The Wisdom of Crowds. New York, Random House.

The New School. (2010) 'The New School -- Curriculum'. Available at http://www.tnsk.org/TNS/curriculum.htm (accessed July 22, 2010).

Toch, T. (2006). Margins of Error: The Education Testing Industry in the No Child Left Behind Era. Washington, D.C., Education Sector.

Tyack, D. (2001) 'School for Citizens: The Politics of Civic Education from 1790 to 1990', in G. Gerstle and J. Mollenkopf (eds.) E Pluribus Unum? Contemporary and Historical Perspectives on Immigrant Political Incorporation. New York, Russell Sage Foundation: 331-70.

Tyack, D. and L. Cuban (1995) Tinkering Toward Utopia: A Century of Public School Reform. Cambridge, MA, Harvard University Press.

Ulluci, K. and J. Spencer (2009) 'Unraveling the Myths of Accountability: A Case Study of the California High School Exit Exam'. The Urban Review 41: 161-73.

Wasserman, S. (2001) 'Quantum Theory, The Uncertainty Principle, and the Alchemy of Standardized Testing'. Phi Delta Kappan 83(1): 28-40.

Wiley, E. W., W. J. Mathis and D. R. Garcia (2005) 'The Impact of the Adequate Yearly Progress Requirement of the Federal "No Child Left Behind" Act on Schools in the Great Lakes Region.'

Winerip, M. (2006) 'Standardized Tests Face a Crisis Over Standards.' New York Times. 
